\title{
Multiple linear regression model for forecasting Bluetongue disease outbreak in sheep of North-west agroclimatic zone of Tamil Nadu, India
}

\author{
G. Selvaraju, A. Balasubramaniam, D. Rajendran, D. Kannan and M. Geetha
}

Department of Veterinary Epidemiology and Preventive Medicine,

Veterinary College and Research Institute, Namakkal - 637 002, Tamil Nadu, India

Corresponding author: Selvaraju Ganapathy, email: g.selvaraju@tanuvas.org.in

Received: 16-08-2012, Accepted: 15-10-2012, Published online: 11-03-2013

How to cite this article: Selvaraju G, Balasubramaniam A, Rajendran D, Kannan D and Geetha M (2013) Multiple linear regression model for forecasting Bluetongue disease outbreak in sheep of north-west agroclimatic zone of Tamil Nadu, India, Vet. World 6(6): 321-324, doi: 10.5455/vetworld.2013.321-324

\begin{abstract}
Aim: A study was undertaken to develop a forecasting model for predicting bluetongue outbreaks in North-west agroclimatic zone of Tamil Nadu, India.

Materials and Methods: Eleven bluetongue outbreaks were characterised by active and passive surveillances for a period of twelve years and used in this study. Meteorological data comprising of maximum and minimum temperatures, relative humidity, rainfall and wind speed were collected and used as the multiple predictor variables in the multiple liner regression model.

Results: A multiple liner regression model was developed for the North-west zone of Tamil Nadu. Values of the dependant variables were less than or greater than one, and indicated remote or greater chances of bluetongue outbreaks respectively. The monthly mean maximum and minimum temperatures, relative humidity at $8.30 \mathrm{~h}$ and at $17.00 \mathrm{~h}$ IST, wind speed, and monthly total rainfall of $29.1-31.0^{\circ} \mathrm{C}, 20.1-22.0^{\circ} \mathrm{C}, 80.1-85.0 \%, 65.1-70.0 \%, 3.1-5.0 \mathrm{~km} / \mathrm{h}$ and $<200 \mathrm{~mm}$ respectively, were identified as the ideal climatic conditions for increased numbers of bluetongue outbreaks in this zone.
\end{abstract}

Conclusion: Based on the values obtained from the prediction model, stake holders can be warned timely through the media to institute suitable prophylactic measures against bluetongue, to avoid economic losses due to disease.

Key words: agroclimatic zone, bluetongue, forecating model, multiple regression, sheep

\section{Introduction}

Bluetongue (BT), an infectious and noncontagious disease of ruminants, is caused by BT virus (BTV), an RNA virus which belongs to the Orbivirus genus of the family Reoviridae [1]. The disease is characterized by mortality rates as high as $70 \%$ in highly susceptible sheep populations [2]. The estimated annual economic loss due to BT outbreak was Rs. 52 lakhs in TamilNadu and about $\$ 3$ billion worldwide [3,4]. Bluetongue is endemic in Indian states of Tamil Nadu, Andhra Pradesh, Karnataka, Maharashtra, Gujarat, Rajasthan, Haryana, Himachal Pradesh and Jammu and Kashmir. In Tamil Nadu, 22 out of 23 districts were reported to be affected by the BTV [5]. More than 27 Culicoides species have been identified in India, and Culicoides imicola, $C$. peregrinus, $C$. oxystoma and $C$. brevitasis are the predominant species involved in the transmission of BT in Tamil Nadu [5, 6,7].

The occurrence of BT depends on timing and amount of rainfall. In India, most of the annual BT outbreaks occur during south-west and north-east monsoon seasons (June to December), which is directly correlated with the number of adult culicoides

This article is an open access article licensed under the terms of the Creative Commons Attribution License (http://creativecommons. org/licenses/by/2.0) which permits unrestricted use, distribution and reproduction in any medium, provided the work is properly cited. vectors. Culicoides vectors are significantly affected by the climate and weather and frequently influence the incidence and overall severity of BT [6]. BTV may be introduced to new regions by the movement of infected animals, but will survive in a new region only if competent vectors and sufficient susceptible hosts are present. Environmental temperature [8], relative humidity [9], effective rainfall [10,11], wind direction and wind speed [12] have been implicated in the natural spread of infected culicoides vectors.

Timely announcement of weather forecasting is a useful tool for sheep owners [5] to carry out disease control activities to curtail the outbreaks and eliminate the disease and infection in the shortest possible time frame, using the most cost-effective ways. Hence, the research work was carried out to develop an effective BT forecasting system using maximum and minimum temperature, relative humidity, rainfall and wind speed in North-west agroclimatic zone of Tamil Nadu, India.

\section{Materials and Methods}

Study zone: The study was carried out in the Northwest agroclimatic zone of Tamil Nadu, India. Twenty per cent of the total Tamil Nadu sheep population mainly comprises Mecheri and Trichy Black breeds. Tamil Nadu, located in the peninsular Deccan Plateau of India, is divided into seven agroclimatic zones viz. Cauvery Delta; North-East; West; North-West; High 
Table-1. Correlation of the monthly mean maximum and minimum temperatures and relative humidity at $8.30 \mathrm{~h} \mathrm{IST}$, with the number of bluetongue outbreaks recorded

\begin{tabular}{|c|c|c|}
\hline \multicolumn{2}{|c|}{ Meteorological parameters } & \multirow{2}{*}{$\begin{array}{l}\text { Number of } \\
\text { outbreaks }\end{array}$} \\
\hline Element & Categorized Values & \\
\hline Monthly mean maximum temperature & $\begin{array}{l}29.1-30.0 \\
30.1-31.0 \\
31.1-32.0 \\
32.1-33.0 \\
33.1-34.0 \\
34.1-35.0 \\
35.1-36.0 \\
36.1-37.0\end{array}$ & $\begin{array}{l}4 \\
5 \\
0 \\
0 \\
1 \\
1 \\
0 \\
0\end{array}$ \\
\hline Monthly mean minimum temperature & $\begin{array}{l}18.1-19.0 \\
19.1-20.0 \\
20.1-21.0 \\
21.1-22.0 \\
22.1-23.0 \\
23.1-24.0 \\
24.1-25.0\end{array}$ & $\begin{array}{l}0 \\
0 \\
5 \\
4 \\
0 \\
1 \\
1\end{array}$ \\
\hline Monthly mean $\mathrm{RH} 8.30 \mathrm{~h}$ IST & $\begin{array}{l}65.1-70.0 \\
70.1-75.0 \\
75.1-80.0 \\
80.1-85.0\end{array}$ & $\begin{array}{c}0 \\
0 \\
1 \\
10\end{array}$ \\
\hline
\end{tabular}

Altitude; South; and high rainfall zones; based on soil characteristics, rainfall distribution, irrigation patterns, cropping patterns and other ecological and social characteristics.

Outbreak data: Bluetongue outbreak particulars were collected by both active and passive surveillances as per protocol prescribed by Martin [13].

A total of five outbreaks were identified out of nine suspected flocks through active surveillance for a period of two years (June 2007 to May 2009). Based on the history and clinical symptoms in affected sheep, whole unclotted (EDTA) blood was collected as per standard protocol prescribed by CFSPH [2] and shipped on gel packs to the Vaccine Research Centre Viral Vaccines, Centre for Animal Health Studies, Tamil Nadu Veterinary and Animal Sciences University, Chennai, Tamil Nadu and Division of Virology, Indian Veterinary Research Institute, Mukteswar, Uttranchal for confirmation of bluetongue.

A total of six outbreaks were identified through passive surveillance for a period of twelve years (June 1997 to May 2009) from data available at Animal Disease Investigation Units, Salem and Dharmapuri, Tamil Nadu.

Meteorological data: Meteorological data comprising monthly mean i). maximum temperature; ii). minimum temperature; iii). relative humidity at $8.30 \mathrm{~h} \mathrm{IST}$; iv). relative humidity at $17.00 \mathrm{~h} \mathrm{IST;} \mathrm{v).} \mathrm{total} \mathrm{rainfall;} \mathrm{and}$ vi). wind speed for the period spanning June 1997 to May 2009 were collected from Animal Feed Analytical and Quality Control Laboratory, Veterinary College and Research Institute, Namakkal, Tamil Nadu and Regional Meteorological Centre, Indian Meteorological Department, Chennai, Tamil Nadu, and used in this study. Tables- 1 and 2 indicate the number of outbreaks experienced and values of the predictor variables.

Statistical analysis: Statistical Package for Social
Table-2. Comparison of monthly mean relative humidy at $17.00 \mathrm{~h} \mathrm{IST}$, total rainfall $(\mathrm{mm})$ and wind speed $(\mathrm{km} / \mathrm{h})$, with the number of bluetongue outbreaks experienced

\begin{tabular}{|c|c|c|}
\hline \multicolumn{2}{|c|}{ Meteorological parameters } & \multirow{2}{*}{$\begin{array}{l}\text { Number of } \\
\text { outbreaks }\end{array}$} \\
\hline Element & Categorized Values & \\
\hline Monthly mean $\mathrm{RH}$ at $17.00 \mathrm{~h}$ IST & $\begin{array}{r}40.1-45.0 \\
45.1-50.0 \\
50.1-55.0 \\
55.1-60.0 \\
60.1-65.0 \\
65.1-70.0\end{array}$ & $\begin{array}{l}0 \\
1 \\
0 \\
1 \\
0 \\
9\end{array}$ \\
\hline Monthly total rainfall (mm) & $\begin{array}{c}0-100 \\
101-200 \\
201-300 \\
301-400 \\
401-500\end{array}$ & $\begin{array}{l}7 \\
4 \\
0 \\
0 \\
0\end{array}$ \\
\hline Monthly mean wind speed $(\mathrm{km} / \mathrm{h})$ & $\begin{array}{l}1.1-2.0 \\
2.1-3.0 \\
3.1-4.0 \\
4.1-5.0 \\
5.1-6.0 \\
6.1-7.0 \\
7.1-8.0 \\
8.1-9.0\end{array}$ & $\begin{array}{l}1 \\
1 \\
4 \\
4 \\
0 \\
0 \\
0 \\
1\end{array}$ \\
\hline
\end{tabular}

Survey (SPSS) ${ }^{\circledR} 15.00$ for windows, available at Tamil Nadu Veterinary and Animal Sciences University, Chennai, Tamil Nadu, was used as applied by plant pathologist Esker et al. [14], and validated with existing data.

Multiple linear regression, generalises the prediction methodology to allow for multiple predictor variables, such as monthly mean maximum temperature, minimum temperature, relative humidity (at 8.30 $\mathrm{h}$ IST), relative humidity (at $17.00 \mathrm{~h} \mathrm{IST),} \mathrm{wind} \mathrm{speed}$ and total rainfall correspondingly. Multiple linear regression model used as follows;

$$
y=\beta_{0}+\beta_{1} w_{1}+\beta_{2} w_{2}+\beta_{3} w_{3}+\beta_{4} w_{4}+\beta_{5} w_{5}+\beta_{5} w_{5}+\beta_{6} w_{6}
$$

Where,

$y$-Dependant variable,

$\beta_{0}-$ Constant,

$\beta_{(1-6)}$-Unstandardised coefficient for each predictor variables,

$w_{1}$ - Monthly mean maximum temperature $\left({ }^{\circ} \mathrm{C}\right)$,

$w_{2}$ - Monthly mean minimum temperature $\left({ }^{\circ} \mathrm{C}\right)$,

$w_{3}$-Relative humidity at $8.30 \mathrm{~h} \mathrm{IST} \mathrm{(percent),}$

$w_{4}$-Relative humidity at $17.00 \mathrm{~h} \mathrm{IST}$ (percent),

$w_{5}$-Monthly total rainfall $(\mathrm{mm})$,

$w_{6}$-Monthly mean wind speed $(\mathrm{km} / \mathrm{h})$,

$w_{1}$ to $w_{6}$ - Predictor variables

\section{Results}

The multiple linear regression model for forecasting of BT outbreaks in North-west agroclimatic zone of Tamil Nadu, India was as follows;

$y=(220.453)+\left(-8.922 w_{1}\right)+\left(5.358 w_{2}\right)+\left(0.183 w_{3}\right)+$ $\left(-0.846 w_{4}\right)+\left(0.049 w_{5}\right)+\left(-2.412 w_{6}\right)$

Model summary and regression co-efficient are shown in Table-3. The model was developed following predictor variables working ranges and fixed based on the climatic conditions that prevailed over the past 12 
Table-3. Model summary and regression coefficient for the developed model

\begin{tabular}{|c|c|c|c|c|c|c|c|c|c|c|}
\hline \multicolumn{11}{|c|}{ Model Summery } \\
\hline \multirow[t]{2}{*}{ Model } & \multirow[t]{2}{*}{$\mathbf{R}$} & \multirow[t]{2}{*}{ R Square } & \multirow[t]{2}{*}{ Adjusted R Square } & \multicolumn{2}{|c|}{ SE of Estimate } & \multicolumn{5}{|c|}{ Change Statistics } \\
\hline & & & & & & R Square Change & F Change & df1 & df2 & Sig. F Change \\
\hline 1 & $0.895^{\mathrm{a}}$ & 0.801 & 0.561 & & & 0.801 & 3.346 & 6 & 5 & 0.103 \\
\hline \multicolumn{11}{|c|}{ a. Predictors : (Constant), SE : Standard error } \\
\hline \multicolumn{11}{|c|}{ Regression Coefficient $^{\mathrm{a}}$} \\
\hline \multirow[t]{2}{*}{ S. No. } & \multirow[t]{2}{*}{ Model } & & & \multicolumn{2}{|c|}{ Unstandardised Coefficient } & \multicolumn{3}{|c|}{ Standardised Coefficient } & \multirow[t]{2}{*}{$\mathbf{t}$} & \multirow[t]{2}{*}{ Sig. } \\
\hline & & & & B & SE & & Beta & & & \\
\hline $\begin{array}{l}1 . \\
2 . \\
3 . \\
4 . \\
5 . \\
6 . \\
7 .\end{array}$ & $\begin{array}{l}\text { (Const } \\
\text { Monthly } \\
\text { Monthl] } \\
\text { Monthl] } \\
\text { Monthly } \\
\text { Monthly } \\
\text { Wind s }\end{array}$ & $\begin{array}{l}\text { mean max } \\
\text { mean mini } \\
\text { mean } \mathrm{RH} \\
\text { mean } \mathrm{RH} \\
\text { total rainfa } \\
\text { eed }(\mathrm{km} / \mathrm{h})\end{array}$ & $\begin{array}{l}\text { imum temperature } \\
\text { mum temperature } \\
8.30 \mathrm{~h} \mathrm{IST}) \\
17.30 \mathrm{~h} \text { IST) } \\
\|(\mathrm{mm})\end{array}$ & $\begin{array}{c}220.453 \\
-8.922 \\
5.358 \\
0.183 \\
-0.846 \\
0.049 \\
-2.412\end{array}$ & $\begin{array}{c}228.833 \\
7.677 \\
6.350 \\
1.373 \\
1.360 \\
0.036 \\
2.632\end{array}$ & & $\begin{array}{l}. .963 \\
1.611 \\
.837 \\
.058 \\
0.603 \\
.434 \\
0.334\end{array}$ & & $\begin{array}{c}0.38 \\
-1.16 \\
0.84 \\
0.13 \\
-0.6 \\
1.36 \\
-0.9\end{array}$ & $\begin{array}{l}0.298 \\
0.437 \\
0.899 \\
0.561 \\
0.232 \\
0.401\end{array}$ \\
\hline
\end{tabular}

years (1997-2009).

Monthly mean maximum temperature $\left({ }^{\circ} \mathrm{C}\right): 29.12-36.73$

Monthly mean minimum temperature $\left({ }^{\circ} \mathrm{C}\right): 18.43-24.41$

Relative humidity at $8.30 \mathrm{~h}$ IST (per cent): $69.17-82.42$

Relative humidity at $17.00 \mathrm{~h} \mathrm{IST}$ (percent): $42.33-67.83$

Monthly total rainfall (mm): $1.31-409.20$

Monthly mean wind speed $(\mathrm{km} / \mathrm{h}): 1.33-8.20$

\section{Discussion}

Forecasting model: In this model, preceding 30 day averages of the predictor variables are used to give early warning on a daily basis. The model is qualitatively valid only for the study zone within the working range. If the value of a dependant variable is less than one $(y<1)$, there is a remote chance for a disease outbreak; and if greater than one $(y>1)$, there is an increased chance of disease outbreaks as previously reported by Jong [15]. It is concluded that based on results of the prediction model, stake holders may be continuously advised about possible future bluetongue outbreaks through the media, for instituting suitable prophylactic measures to avoid economic losses due to the disease.

Correlation of meteorological data with outbreaks Monthly mean temperature vs. bluetongue outbreaks: In this zone, BT outbreaks were increased when the monthly mean maximum and minimum temperatures ranged from 29.1 to $31.0^{\circ} \mathrm{C}$ and 20.1 to $22.0^{\circ} \mathrm{C}$ respectively (Table 1). The vector activity is positively correlated with temperature rises and reaches a maximum between 28 and $30^{\circ} \mathrm{C}[16,17]$. Paweska et al. [18] also recorded highest BTV infection rates at $25^{\circ} \mathrm{C}$ and highest transmission potential at $30^{\circ} \mathrm{C}$ by Culicoides imicola and C. bolitinos.

Monthly mean relative humidity vs. bluetongue outbreaks: High relative humidity was found to be a favourable factor for the development of Culicoides species [19] and it can positively alter the level of activity of Culicoides midges [9]. Similarly, more outbreaks were recorded during high monthly mean relative humidity (both at $8.30 \mathrm{~h}$ IST and $17.00 \mathrm{~h}$ IST) in this study (Table1 and 2).

Monthly total rainfall vs. bluetongue outbreaks: There were more outbreaks with monthly total rainfall ranges of $0-100 \mathrm{~mm}$, followed by $100-200 \mathrm{~mm}$ (Table 2 ). This indicated that low to moderate levels of rainfall are sufficient for the multiplication of vectors, and that heavy rains inundate and erode the breeding sites as earlier observed by Braverman [12]. Ward [20] also reported that rainfall of two to three inches (50 to 75 $\mathrm{mm}$ ) was sufficient to allow the vector species and Subramanian and Piramanayagam [10] opined that rainfall prevailing during the months of November (148 $\mathrm{mm})$ and December $(176 \mathrm{~mm})$ predisposes high morbidity and mortality rate in Tirunelveli region of Tamil Nadu, India.

Monthly mean wind speed vs. bluetongue outbreaks: Increased numbers of outbreaks were observed with monthly mean wind speed ranges of 3.1 to $5.0 \mathrm{~km} / \mathrm{h}$ when compared to lower or higher wind speed ranges (Table-2). This is in accordance with the findings of Ausvetplan [21] which reported that the lower wind speed encouraged local spread, as the insects would not fly in higher wind speeds $(>8 \mathrm{~km} / \mathrm{h})$. Moreover, low wind speeds favour vector seeking of hosts for blood meal feeding, mating, egg laying and shelter as stated by Sellers [22]. Hence, wind can aid the passive dispersal of infected vector as reported by Saegerman et al. [16].

\section{Conclusion}

In agricultural sciences, several models were developed for the forecasting of plant diseases. However, in veterinary science forecasting models are scanty, especially in India. In the present study, meteorological parameters were correlated with BT outbreaks and a multiple linear regression model was developed and validated with available data. This is a pioneer model for the North-west agroclimatic zone of Tamil Nadu, India. Based on the value obtained from 
the prediction model, stake holders can be continuously advised through the media to institute suitable prophylactic measures to avoid economic losses due to bluetongue.

\section{Authors' contribution}

GS and AB designed the study. GS conducted the study and analyzed the data. DR, DK and MG drafted and revised the manuscript. All authors read and approved the final manuscript.

\section{Acknowledgements}

The authors are thankful to Registrar, Tamil Nadu Veterinary and Animal Sciences University, Chennai, Tamil Nadu, State Department of Animal Husbandry, Tamil Nadu and Division of Virology, Indian Veterinary Research Institute, Mukteswar, Uttranchal for successful development of this forecasting model.

\section{Competing interests}

Authors declare that they have no competing interest.

\section{References}

1. Sperlova, A. and Zendulkova, D. (2011). Bluetongue: a review. Vet. Medicina, 56: 430-452.

2. CFSPH. (2006). Centre for Food Security and Public Health (CFSPH). Bluetongue. Institute for international Cooperation in Animal Biological: an OIE Collaborating Centre, College of Veterinary Medicine, Iowa State University, Iowa.

3. Tabachnick, W.J., Robertson, M.A. and Murphy, K.E. (1996). Culicoides variipennis and bluetongue disease, Ann. NY. Acad. Sci., 791: 219-226.

4. Ramesh, N., Rajesh Kannan, V., Karthikeyan, K., Nanthakumar, K. and Karthik Raja, R. (2009). Sero Diagnosis of Bluetongue virus Infection and Isolation of Virus in Embryonated Chicken Egg and BHK-21 Cell Line. Res. J. Microbiol., 4: 186-193.

5. Ilango, K. (2006). Bluetongue virus outbreak in Tamil Nadu, southern India: Need to study the Indian biting midge vectors, Culicoides latreille (Diptera: Ceratopogonidae). Curr. Sci., 90: 163-167.

6. Mellor, P.S., Baylis, M., Peter P.C. and Mertens, (2009). Bluetongue. $1^{\text {st }}$ Edn., Academic Press Elsiver publication, London. Pp: 167-196.

7. Sreenivasulu, D., Rao, M.V.S., Reddy, Y.N. and Gard, G.P. (2004). Overview of bluetongue disease, viruses, vectors, surveillance and unique features: the Indian sub-continent and adjacent regions. Vet. Ital., 40: 73-77.

8. Prasad, G., Rupinder and Minakshi (2008). Current status of bluetongue disease in India and its pathogenesis in relation to host and climate change. Indian J. Vet. Pathol., 32: 111-124.

9. Wittmann, E.J. and Baylis, M. (2000). Climate changes: Effects on Culicoides transmitted viruses and implications for UK. Vet. J., 160: 107-117.

10. Subramanian, K.S. and Piramanayagam, S. (2001). Epidemiological observation on bluetongue in Tirunelveli region. Indian Vet. J., 78: 945-946.

11. Racloz, V., Presi, P., Vounatsou, P., Schwermer, H., Casati, S., Vanzetti, T., Groit, C. and Stark, K.D.C. (2007). Use of mapping and statistical modeling for the prediction of bluetongue occurrence in Switzerland based on vector biology. Vet. Ital., 43: 513-518.

12. Braverman, Y., Chechik, F. and Mullens, B. (2001). The interaction between climatic factors and bluetongue outbreaks in Israel and the Eastern Mediterranean, and the feasibility of establishing bluetongue-free zones. Israel $J$. Vet. Med., 56: 99-109.

13. Martin, S.W. (1993). Veterinary epidemiology: Principles and methods, First Indian reprint, International Book Distributing Co., Lucknow, India.

14. Esker, P.D., Sparks, A.H., Campbell, L., Guo, Z., Rouse, M., Silwal, S.D., Tolos, S., Van Allen, B. and Garrett, K.A. (2008). Ecology and Epidemiology in R: Disease Forecasting. The Plant Health Instructor, DOI:10.1094/ PHI -A-2008-0129-01.

15. Jong, M.C.M. (1995). Mathematical modeling in veterinary epidemiology: why model building is importance. Prev. Vet. Med., 25: $183-193$.

16. Saegerman, C., Berkvens, D. and Mellor P.S. (2008). Bluetongue epidemiology in the European union. Emerg Infect Dis., 14:539-544.

17. Mayo, C. (2010). Prevalence and risk factors associated with bluetongue virus among Colorado sheep flocks. Master Science Thesis. Submitted to the Colorado State University, Fort Collins, Colorado.

18. Paweska, J.T., Venter, G.J. and Mellor, P.S. (2002). Vector competence of South African Culicoides species for bluetongue virus serotype 1 (BTV-1) with special reference to the effect of temperature on the rate of virus replication in C. imicola and C. bolitinos. Med. Vet. Entomol., 16: 10-21.

19. Narladkar, B.W., Shastri, U.V. and Shivpuje, P.R. (1993). Seasonal prevalence of Culicoides sp. (Diptera: Ceratopogonidae) in Marathawada region. Indian J. Anim. Sci., 63: 1140-1145.

20. Ward, M.P. (1994). Climatic factors associated with the prevalence of bluetongue virus infection of cattle herds in Queensland, Australia.Vet. Rec., 134: 407-410.

21. Ausvetplan, (1996). Disease Strategy, Bluetongue. Australian veterinary Emergency Plan Manual, Ausvetplan $2^{\text {nd }}$ Edn., Agriculture and Resource Management Council of Australia and New Zealand, 1-12.

22. Sellers, R.F. (1992). Weather, Culicoides and the distribution and spread of bluetongue and African horse sickness viruses. In Bluetongue, African Horse Sickness and related Orbiviruses. Eds. Walton, T.E. and B.I. Osburn, CRC Press, Boca Raton, Florida, pp. 284-290. 